\title{
REKONSTRUKSI PENGATURAN PEMBINAAN LEMBAGA KEOLAHRAGAAN PASCA PUTUSAN MAHKAMAH KONSTITUSI NOMOR 19/PUU-XII/2014
}

\author{
Hermawan Dwi Putra, Tunggul Anshari, Mohammad Fadli \\ Magister Ilmu Hukum, Program Pasca Sarjana Universitas Brawijaya \\ Jl. MT. Haryono No. 169 Malang, Jawa Timur, Indonesia \\ E-mail :putra@ub.ac.id
}

\begin{abstract}
The study, titled "Reconstruction Of The Sport Institute Coaching Arragements In Legislation" aims to analyze the No. 3 Year 2005 about the National Immune System in the second generation of adults, the political system in Indonesia and the form of breaking up in the Constitution. The method used in this study is normative legal research, the approach taken Law approach, historical approach and comparative approach, there are three sources of legal material, namely the source of primary, secondary and tertiary legal materials. The legal material collection technique analyzes the Minutes of the Indonesian National System, a study of students by collecting and analyzing the population, as well as researchers from the internet. The analysis of the law in the study with descriptive descriptive techniques of the. The results showed that the problem can be concluded as the cause of the obscurity of the norms of the National Sports Committee in 36 articles (1) and (3), based on the SKN Draft Bill, the KONI is written National Sports with the aim to protect the citizenship of KONI. KOI only has to go to the internet and it will take an internal competition. The overlapping of authority in the development of sports due to the absence of legal certainty. Giving the concept of setting up KONI and KOI after being in the mid-1980s, KONI and KOI will eventually be led by a third, Reconstruction in the SKN Law makes it appear that it has a disadvantage so it does not cause conflict.
\end{abstract}

\section{Keywords : Reconstruction, Sport, Constitution.}

\begin{abstract}
Abstrak
Penelitian yang berjudul "Rekonstruksi Pengaturan Pembinaan Lembaga Keolahragaan Pasca Putusan Mahkamah Konstitusi Nomor 19/PUU-XII/2014” bertujuan menganalisa Undang-Undang No 3 Tahun 2005 tentang Sistem Keolahragaan Nasional terhadap kedua induk keolahragaan, sistem keolahragaan di Indonesia dan bentuk putusan Mahkamah Konstitusi. Metode yang dipergunakan dalam penelitian ini adalah penilitian hukum normatif, pendekatan yang dilakukan yaitu pendekatan Undang-Undang, pendekatan Historis dan pendekatan komparatif, sumber bahan hukum ada tiga yakni sumber bahan hukum primer, sekunder dan tersier. Teknik pengumpulan bahan hukum adalah dengan menganalisa Risalah Undang-Undang Sistem Keolahragaan Indonesia,
\end{abstract}


studi kepustakaan dengan mengumpulkan dan menganalisis bahan-bahan kepustakaan, serta penelurusan bahan dari internet. Analisis bahan hukum dalam penelitian ini dilakukan dengan teknik deskriptif kualitatif yaitu mendeskripsikan pokok-pokok permasalahan atau isu hukum yang diangkat, dalam penelitian ini tentang akibat hukum dan upaya hukum. Hasil Penelitian diperoleh bahwa permasalahan dapat disimpulkan penyebab kekaburan norma frasa Komite Olahraga Nasional yang ada didalam pasal pasal 36 ayat (1) dan (3), berdasarkan Risalah RUU SKN adalah KONI ditulis dengan huruf kecil yaitu Komite Olahraga Nasional dengan tujuan untuk membatasi kewenangan KONI. KOI hanya melakukan pemberangkatan atlet ke ajang internasional dan mengadakan perlombaan internasional sesuai dengan pasal Pasal 44 ayat (1),(2),(3) dan (4) dalam UU SKN. Terjadinya tumpang tindih kewenangan dalm pembinaan keolahragaan karena tidak adanya kepastian hukum. Memberikan konsep mempersatukan KONI dan KOI menjadi sutu wadah kelembagaan keolahragaan, KONI dan KOI selanjutnya akan di pimpin oleh satu ketua, Rekonstruksi dalam UU SKN memperjelas frasa yang memiliki kekaburan sehingga tidak menimbulkan konflik.

\section{Kata Kunci: Rekonstruksi, Olahraga, Konstitusi}

\section{A. PENDAHULUAN}

Perkembangan olahraga, khususnya di Indonesia, semakin pesat. Aspek-aspek non olahraga juga dirasakan pengaruhnya dalam olahraga ini. Aspek hukum dalam kegiatan keolahragaan di Indonesia misalnya terlihat dari tujuan negara Indonesia sebagaimana tercantum dalam alinea keempat Pembukaan Undang-Undang Dasar Negara Republik Indonesia Tahun 1945 yaitu "melindungi segenap bangsa Indonesia dan seluruh tumpah darah Indonesia dan untuk memajukan kesejahteraan umum, mencerdaskan kehidupan bangsa, dan ikut melaksanakan ketertiban dunia yang berdasarkan kemerdekaan, perdamaian abadi dan keadilan sosial..."

Untuk mewujudkan tujuan negara dalam kegiatan keolahragaan di Indonesia telah disahkan landasan hukum untuk kegiatan keolahragaan yaitu Undang- Undang Nomor 3 Tahun 2005 tentang Sistem Keolahragaan Nasional. Pemerintah harus banyak turut campur dalam kehidupan rakyat yang mendalam di semua sektor. Campur tangan itu tertuang dalam ketentuan perundang-undangan, baik dalam bentuk undang-undang maupun peraturan pelaksana lainnya yang dilaksanakan oleh admnistrasi negara yang menyelenggarakan tugas servis public. ${ }^{1}$

Keolahrgaan Nasional tersebut membangkitkan sejuta asa bagi bangsa Indonesia, seperti terciptanya iklim keolahragaan yang kondusif yang ditandai dengan tertatanya sistem organisasi keolahragaan secara rapi, tersedianya standar minimal sarana dan prasarana

1 Sjahran Basah, Eksistensi dan Tolok Ukur Badan Peradilan Administrasi di Indonesia, Alumni, Bandung, 1985, hlm 10 
olahraga di mana-mana, semaraknya aktivitas olahraga dari segala lapisan masyarakat, baik laki-laki maupun perempuan, dari anak-anak sampai orang tua, tersedianya tenaga keolahragaan berkualitas dalam jumlah yang memadai. Semua itu berujung pada meningkatnya prestasi olahraga Indonesia, baik di tingkat nasional maupun internasional, meningkatnya status kesehatan dan kebugaran masyarakat Indonesia, yang pada gilirannya dapat mengangkat harkat dan martabat bangsa Indonesia itu sendiri.

Keterlibatan pemerintah untuk mendukung keolahragaan juga harus didasarkan pada asas legalitas (legaliteitsbeginsel), karena sebagai dasar penting dari negera hukum. Indonesia adalah negera hukum di mana disebutkan dalam pasal 1 ayat (3) UUD Negara Republik Indonesia Tahun 1945. Keharusan mendasar pada asas legalitas setiap tindakan hukum pemerintah di bidang publik ini mengandung arti mensyaratkan adanya hukum tertulis atau peraturan perundang-undangan. Menurut Philipus M. Hadjon, ide rechsstaat cenderung ke arah positivisme hukum yang membawa konsekuensi bahwa hukum harus dibentuk secara sadar oleh badan pembentuk undang undang. ${ }^{2}$

Akan tetapi dengan disahkannya Undang-Undang Nomor 3 Tahun 2005 tentang Sistem Keolahragaan Nasional juga berakibat dengan lembaga keolahragaan yang secara resmi memecah Komite Olahraga Nasional Indonesia dan Komite Olimpiade. Sejak saat itu banyak permasalahan yang terjadi dalam dunia keolahragaan dikarenakan dua induk keolahragaan dipimpin oleh dua pemimpin, dan terjadi tumpang tindih dalam menjalankan tugas pembinaan keolahragaan yang dulu dilaksanakan oleh satu pemimpin. Sampai pada akhirnya Komite Olahraga Nasional Indonesia melayangkan gugatan kepada KOI melalui Mahkamah Konstitusi untuk melakukan Judicial Review dalam Undang-Undang No 3 tentang Sistem Keolahragaan Nasional Tahun 2005 menganai kedudukan KONI dan KOI melalui pasal 36 ayat (1) dan (3) Undang-Undang Sistem Keolahragaan Nasional. Karena adanya kekaburan makna Frasa Komite Olahraga, sehingga muncul dua induk organisasi olahraga, yaitu KONI dan KOI yang dulu menjadi satu kesatuan dan sekarang terpisah sehingga memunculkan aspek negatif dalam masalah kedudukan hukum pembinaan keolahragaan.

\section{B. RUMUSAN PERMASALAHAN}

Berdasarkan latar belakang permasalahan diatas, dalam penelitian ini diambil beberapa permasalahan yang akan diteliti, yaitu :

1. Apa penyebab kekaburan Norma Frasa Komite Olahraga Nasional dalam pasal 36 ayat (1) dan (3) dalam Undang-Undang Nomor 3 Tahun 2005 tentang Sistem Keolahragaan Nasional. Bagaimana Implikasi Hukum dari Kekaburan Norma Frasa Komite Olahraga Nasional dalam pasal 36 ayat (1) dan (3) Undang-Undang Nomor 3

${ }^{2}$ Philipus M. Hadjon, Ide Negara Hukum dalam Sistem Ketatanegaraan Republik Indonesia, Makalah pada Bagir Manan (Ed). Kedaulatan Rakyat, Hak Asasi Manusia, dan Negara Hukum, Kumpulan Esai Dalam Rangka 70 Tahun R. Sri Soemantri Martosoewignjo, Gaya Media Pratama, Jakarta: 1996, hlm 80. 
Tahun 2005 terhadap kedudukan KONI dan KOI?

2. Bagaimana Konsep Rekonstruksi terhadap Undang-Undang Nomor 3 Tahun 2005 tentang Sistem Keolahragaan Nasional Untuk mempersatukan KONI dan KOI pasca putusan Mahkamah Konstitusi Nomor 19/PUU-XII/2014?

\section{METODE PENELITIAN}

Metode yang digunakan dalam penilitian ini yuridis normatif. Metode Pendekatan Penelitian. Dari konsep penilitian normatif Sesuai dengan jenis penelitiannya yakni penelitian hukum normatif maka dapat digunakan lebih dari satu pendekatan analisis bahan hukum dalam penelitian ini dilakukan dengan teknik deskriptif kualitatif. Dengan demikian data diolah secara kualitatif (.Jhonny Ibrahim, 2006, 46). Pendekatan yang digunakan adalah pendekatan perundang- undangan (statute approach), pendekatan historis (historical approach), dan pendekatan berbandingan (comparative approach). ${ }^{3}$

\section{PEMBAHASAN}

\section{Pertumbuhan Lembaga Keolahragaan}

Proklamasi Negara Indonesia pada Tanggal 17 Agustus 1945 merupakan pintu gerbang terbukanya kebebasan bangsa Indonesia dari penjajahan. Peristiwa tersebut merupakan babak baru juga terhadap perkembangan olahraga di Indonesia. Setelah Indonesia merdeka pemerintah mempunyai keinginan agar Indonesia dapat tampil di gelangang International.

Pemerintah Indonesia melalui Kementerian Pendidikan dan Pengajaran melaksanakan program-program pengembangan keolahragaan di Indonesia. Akan tetapi beberapa peristiwa keolahragaan yang menandai perkembangan olahraga pada zaman kemerdekaan yaitu terciptanya organisasi olahraga yang bernama GELORA (Gerakan Latihan Olahraga) kemudian meleburkan diri bersama-sama Djawa Iku Kai yang mempunyai arti pusat olahraga versi jepang. Namun Indonesia masih diwarnai suasana perjuangan untuk mempertahankan kemerdekaan dari pihak Belanda yang ingin berkuasa kembali.

Kementerian Pendidikan Pengajaran mempunyai suatu lembaga di bawah pengawasan kementerian tersebut untuk merencanakan dan melaksanakan pengurusan di bidang keolahragaan di sekolah yang bernama Inspeksi Pendidikan Jasmani adalah organisasi di bawah jawatan pengajaran. Untuk olahraga di masyarakat diurus oleh lembaga di bawah jawatan pendidikan masyarakat. Kementerian Pendidikan dan Pengajaran dalam pelaksanaan tugasnya di bidang pembinaan dan pengembangan fisik antara lain melakukan: a. Penyelenggaran latihan-latihan terpusat dan berkala di

\footnotetext{
${ }^{3}$ Peter Mahmud Marzuki, Penelitian Hukum, Kencana Prenada Media Group, Jakarta: 2005, hlm 96.
} 
kalangan pemuda Indonesia untuk mencapai dan memperoleh kondisi badan yang prima, juga guna mempersiapkan angkatan perang yang pada saat itu masih diperlukan oleh Indonesia; b. Mengusahakan rehabilitasi fisik dan mental bangsa Indonesia untuk dapat berperan serta dalam multievent international. ${ }^{4}$

Ketua KORI dan PORI diangkat langsung oleh Presiden Republik Indonesia meskipun bukan dari bagian departemen pemerintahan, akan tetapi PORI dan KORI tersebut adalah organisasi yang dimasukkan dalam pengawasan Kementrian Pembangunan dan Urusan Pemuda yang memberikan subsidi kepada kedua badan tersebut untuk mendukung administrasinya. Karena keinginan bangsa Indonesia untuk dapat mengikut Olimpiade London dan persiapan untuk memilih atlet-atlet yang akan di berangkatkan ke Olimpiade dalam waktu yang sangat terbatas, maka pengeriman delegasi Indonesia ke Olimpiade London hanya sebatas peninjauan saja.

Setelah keamanan negara pulih maka pada tanggal 25 Desember 1949 PORI melangsungkan kongresnya yang ke -III di Yogyakarta. Dalam kongres tersebut menjawab persoalan dari kongkres ke-II yaitu pemberian hak otonom setiap bagianbagian dari PORI yaitu PSSI, PASI, PELTI, PBKSI dll. Sehingga kembalilah tatanan keoalahragaan seperti dahulu dan PORI tetap berdiri sebagai badan koordinasi organisasi-organisasi otonom tersebut, kecuali namanya menjadi Persatuan Olahraga Indonesia disingkat tetap PORI dan KORI dari Komite Olimpiade Republik Indonesia berganti menjadi KOI yaitu Komite Olimpiade Indonesia. ${ }^{5}$

Peleburan KONI dan KOI menjadi Babak baru organisasi keolahragaan telah lahir, atas usulan PSSI dan PASI maka dalam kongres PORI dan KOI di Jakarta pada tanggal 25-26 Oktober 1951, dan bertepatan dengan PON ke II memutuskan untuk meleburkan PORI ke dalam KOI. Maksud dan tujuan peleburan PORI dan KOI tersebut untuk menjalankan efisiensi dalam pelaksanaan tugas keolahragaan.

Penyelenggaraan jenis-jenis olahraga diserahkan kepada badan-badan otonom seperti PSSI, PASI, PELTI dan lain-lain. Untuk melakukan koordinasi di antara organisasi-organisasi tersebut, serta pembangunan dalam olahraga masih belum ada organisasinya, untuk urusan dengan luar negeri dan pemerintahan diserahkan kepada KOI. Untuk menjamin koordinasi tersebut sebaik-baiknya, organisasi-organisasi otonom tersebut menjadi anggota dari KOI.

Pada tahun 1952, Indonesia berhasil menjadi anggota international olympic committee (IOC) dan pada saat itu juga Indonesia melalui KOI mengirimkan perwakilannya untuk kejuaraan Olimpiade XV di Helsinki.

Pulangnya dari Olimpiade para pelaku keolahragaan mendapat pengalaman baru dalam sistem keolahragaan di Indonesia terutama yang berhubungan dengan aturan

\footnotetext{
${ }^{4}$ H.J.S. Husdarta. Sejarah dan Filsafat Olahraga, Bandung: 2010, hlm 22

${ }^{5}$ Departemen Pendidikan Nasional, Sejarah Lembaga Keolahragaan di Indonesia, Jakarta: 2003.
} 
KOI.

a. KOI masih belum pernah mempunyai anggaran dasar sejak lahirnya sebagai KORI pada tahun 1947, oleh IOC diharuskan menyusun anggaran dasarnya,

b. Gerakan olahraga di Indonesia harus lebih difokuskan agar prestasi lebih meningkat,

c. Memperluas hubungan-hubungan dengan negara lain, untuk mendapatkan pengaruh yang lebih besar pada usaha-usaha pembangunan olahraga di Indonesia sendiri. ${ }^{6}$

Ketiga faktor tersebut mendorong pengurus KOI meninjau kembali aturan KOI. Peninjauan tersebut menghasilkan kesimpulan-kesimpulan sebagai berikut:

a. Tiap-tiap organisasi harus mencurahkan tenaga dan pikirannya sepenuhnya untuk meningkatkan prestasi masing-masing.

b. KOI harus mencurahkan tenaga dan pikirannya sepenuhnya untuk mengusahakan kekuatan yang diperlukan oleh tiap-tiap organisasi dalam melakukan tugas masing masing. Di samping itu juga mengadakan hubungan yang lebih luas dengan organisasi-oraganisasi luar negeri yang ada kaitannya dengan keperluan pembangunan keolahragaan di Indonesia. ${ }^{7}$

Kesimpulan-kesimpulan tersebut mendorong pengurus KOI membenahi dirinya dari dalam yang dasarnya mengambil dari tugas-tugas dari PORI dan KORI dengan mengadakan perubahan yang prinsipil dalam susunan oragnisasi dengan hasil sebagai berikut.

a. Wakil-wakil organisasi yang duduk dalam rapat-rapat KOI bisa berganti-ganti anggota, sehingga dapat berlainan pandangan dari persoalan-persoalan yang sudah ada,

b. Keputusan rapat dari KOI kemungkinan dapat dibatalkan oleh organisasi masing-masing apabila dianggap bertentangan dangan kepentingan organisasi,

c. KOI dengan demikian tidak dapat mengambil keputusan-keputusan yang tegas,

d. Secara organisasi tiap-tiap anggota ikut memikirkan kepentingan-kepentingan organisasi yang lain.

Peraturan yang baru:

a. Anggota KOI terdiri orang-orang yang diusulkan organisasi-organisasi, kepentingan masing-masing jenis olahraga tetap terjamin.

b. Anggota KOI duduk sebagai perseorangan, maka keputusan yang mereka ambil dalam rapat-rapat KOI secara organisasi tidak bisa dibatalkan oleh organisasiorganisasi dan demikian keputusan KOI lebih tegas.

\footnotetext{
${ }^{6}$ Ibid.

${ }^{7}$ Ibid.
} 
c. Secara organisasi masing-masing tidak ikut langsung memikirkan persoalanpersoalan dari KOI dan dengan demikian organisasi dapat mencurahkan tenaga dan fikirannya lebih fokus pada persoalan dengan tidak ada terikat oleh kepentingan masing-masing organisasi.

Peraturan baru ini berkoordinasi antara organisasi tidak erat seperti dalam peraturan lama, tetapi kordinasi ini perakteknya hanya dilakukan dalam soal-soal kepentingan bersama seperti menghadiri Pekan Olahraga Nasional dan Asian Games atau Olimpiade. Dasar pertimbangan-pertimbangan tersebut pengurus KOI mengajukan rencana anggaran dasar untuk kebutuhan KOI.

Keputusan Presiden No.94 Tahun 1962, tanggal 7 Maret 1962 dibentuk Departemen Olahraga, yang tugas wewenang dan lapangan kerja ditetapkan dalam Keputusan Presiden No.131 Tahun 1962 tanggal 9 April 1962, yang antara lain adalah untuk mengatur, mengkoordinir, membimbing, mengawasi, dan di mana perlu menyelenggarakan:

a. Semua kegiatan/usaha di luar, maupun lingkungan sekolah/perguruan tinggi,

b. Pendidikan tenaga-tenaga ahli olahraga (guru, coach),

c. Pembangunan, penggunaan dan pemeliharaan lapangan/bangunan olahraga,

d. Pengiriman olahragawan/team olahraga dari luar negeri ke Indonesia,

e. Persiapan dan penyelenggaraan Asian Games,

Tujuan dari sekretariatan bersama ini adalah untuk berusaha memecahkan permasalah-permasalahan dalam gerakan olahraga. Langkah pertama yang diambil oleh sekretariatan bersama adalah membuat konsepsi Organisasi Olahraga untuk menggantikan DORI. Kosnsep pertama yang dilakukan adalah oleh Sekeretariat Bersama adalah tentang KONI, yang dibuat bersama-sama dengan cabang-cabang Organisasi lainya. Sebenarnya pada dasarnya konsep tersebut tidak ada bedanya dengan DORI, hanya saja lebih sederhana baik organisasi maupun personilnya dan lebih disesuaikan dengan situasi pada saat itu. Dalam konsep KONI itu jelas dari pihak Sekretariat Bersama menginginkan jaminan akan hak asasi, kedaulatan olahraga agar lebih bebas untuk melakukan pembinaan dan mengaturnya.

Pada akhirnya, Presiden Soekarno mengeluarkan Surat Keputusan Presiden NO. 143A dan 156A Tahun 1966, tentang dibentuknya Komite Olahraga Nasional Indonesia yang disebut KONI menggantikan DORI. Pada Tahun 1967 Presiden Soeharto mengukuhkan KONI dengan Keputusan Presiden Nomor 57 Tahun 1967 mencabut SK Presiden (Soekarno) No. 143 A dan 156 A Tahun 1966. Pada tahun yang sama Sri Paku Alam VIII mengundurkan diri sebagai Ketua KOI. Jabatan Ketua KOI kemudian dirangkap oleh Ketua Umum KONI Sri Sultan Hamengkubuwono IX, dengan Sekretaris Jenderal (Sekjen) KONI M.F. Siregar dan Sekretaris KOI Soeworo. Soeworo meninggal, jabatan Sekretaris KOI dirangkap oleh Sekjen KONI M.F. Siregar. Sejak itu dalam AD/ART KONI yang disepakati dalam Musyawarah Olahraga Nasional (Musornas), 
KONI ibarat sekeping mata uang dua sisi yang ke dalam menjalankan tugasnya sebagai KONI dan ke luar berstatus sebagai KOI. IOC kemudian mengakui KONI sebagai NOC Indonesia.

\section{Kedudukan Hukum KONI dan KOI dalam Undang -Undang Nomor 3 Tahun 2005 tentang Sistem Keolahragaan Nasional.}

Kedudukan KONI dalam Undang-Undang Nomor 3 Tahun 2005 tentang Sistem Keolahragaan Nasional adalah KONI atau Komite Olahraga Nasional (KON) frasa yang disebutkan Undang-undang tersebut, menjelaskan bahwa KONI atau KON melakukan pembinaan dalam Negeri meliputi ${ }^{8}$ :

a. Membantu pemerintah dalam membuat kebijakan nasional dalam bidang pengolaan, pembinaan, dan pengembangan olahraga prestasi pada tingkat nasional.

b. Mengoordinasikan induk organisasi cabang olahraga, organisasi olahraga fungsional, serta komite olahraga provinsi dan komite olahraga kabupaten/kota.

c. Melaksanakan pengelolalan, pembinaan, dan pengembangan olahraga prestasi berdasarkan kewenanganya dan.

d. Melaksanakan dan mengoordinasikan kegiatan multi kejuaraan olahraga tingkat nasional.

Kedudukan KONI dalam Undang-Undang Nomor 3 Tahun 2005 tentang Sistem Keolahragaan Nasional adalah KONI atau Komite Olahraga Nasional (KON) frasa yang disebutkan Undang-undang tersebut, menjelaskan bahwa KONI atau KON melakukan pembinaan dalam Negeri meliputi ${ }^{9}$ :

a. Membantu pemerintah dalam membuat kebijakan nasional dalam bidang pengolaan, pembinaan, dan pengembangan olahraga prestasi pada tingkat nasional,

b. Mengoordinasikan induk organisasi cabang olahraga, organisasi olahraga fungsional, serta komite olahraga provinsi dan komite olahraga kabupaten/kota ,

c. Melaksanakan pengelolalan, pembinaan, dan pengembangan olahraga prestasi berdasarkan kewenanganya dan ,

d. Melaksanakan dan mengoordinasikan kegiatan multi kejuaraan olahraga tingkat nasional.

3. Analisis Penyebab Kekaburan Norma Frasa Komite Olahraga pada Pasal 36 Ayat (1) dan (3) dalam Undang-Undang Nomor 3 Tahun 2005 tentang Sistem Keolahragaan Nasional.

Undang-Undang Sistem Keolahragaan Nasional dibentuk berawal dari Surat Presiden Republik Indonesia Nomor: B-10/Pres/6/2005, Tanggal 13 Juni 2005 dengan

\footnotetext{
${ }^{8}$ Seperti dikutip dari laman oldekesra.menkokesra.go.id

${ }^{9}$ Ibid.
} 
perihal Pengantar RUU tentang Sistem Keolahragaan Nasional yang ditujukan kepada Pimpinan DPR RI . DPR setelah menerima surat dari Presiden membagikan dan kepada Anggota Dewan dalam rapat paripurna sesuai dengan pasal 124 ayat (1) Tata Tertib DPR RI . Kemudian berdasarkan keputusan Rapat Badan Musyawarah diputuskan bahwa Rancangan Undang-Undang Sistem Keolahragaan Nasional ditangani oleh Komisi X dan pembicaraan Tingkat I pembahasan atas RUU tersebut dilakukan antara Komisi X dengan Menteri Negara Pemuda dan Olahraga. DPR dengan Komisi X menyamakan presepsi dengan tujuan dalam Undang-Undang ini, Sistem Keolahragaan Nasional merupakan keseluruhan subsistem keolahragaan yang saling terkait secara terencana, terpadu dan berkelanjutan untuk mencapai tujuan keolahragaan nasional.

Subsistem yang dimaksud antara lain pelaku olahraga, organisasi olahraga, dana olahraga, prasarana olahraga dan peran serta masyarakat dan penunjang keolahragaan termasuk ilmu pengetahuan, teknologi, informasi dan industri olahraga nasional. Dalam Undang-Undang Sistem Keolahragaan Negara juga memperhatikan asas desentralisasi, otonomi, peran serta masyarakat, keprofesionalisme, kemitraan, tranparansi dan akuntabilitas serta sistem pengolaan, pembinaan dan pengembangan keolahragaan nasional. Undang-Undang ini juga mengatur mengenai hak dan kewajiban serta kewenangan dan tanggung jawab semua pihak baik dari pemerintah, pemerintah daerah dan masyarakat. Oleh karena itu kekuasaan pemerintah tidak terlepas dari asas legalitas yang telah dimulai sejak munculnya konsep Negara hukum klasik formele rechtsstaat atau liberale rechtsstaat yaitu wetmatigheid van bestuur artinya menurut Undang-Undang. Setiap tindakan pemerintah harus berdasarkan kepada undang-undang .Dengan hadirnya Rancangan Undang-undang tentang Sistem Keolahragaan Nasional tentu tidak akan menyelesaikan semua persoalan yang ada tetapi paling tidak pada saat dibentuk memberikan dasar dan tumbuh kembangnya Sistem Keolahragaan Nasional. Karena Keolahragaan sudah masuk dalam politik di Indonesia .

Penulis akan menjelaskan analisis dari RUU Keolahragaan tentang KOI, pada saat itu tim perumus (TIMUS) menyepakati hasil konsultasi publik ada beberapa masalah yang belum diselesaikan sepeti mengenai eksistensi KOI dalam pasal 36 draft TIMUS, apakah tugas tersebut tetap dijalankan oleh KONI atau perlu dipisah pasal 51 ayat (1) dan (3) konkordon pasal 36. Kepastian hukum dari posisi KONI dan KOI akhirnya di setujui kembali oleh PANJA dan dicantumkan dalam Undang-Undang namun tidak secara rinci hanya sebagai cantolannya saja lalu hanya diusulkan ditempatkan setalah pasal 45 di RUU dan rumusannya diserahkan kepeda pemerintah.

Menurut penulis, dalam pasal 36 tersebut KONI dan KOI tidak ada kepastian hukum karena masyarakat mengharapkan adanya suatu kepastian hukum, karena dengan adanya kepastian hukum masyarakat akan lebih tertib. Hukum bertugas menciptakan kepastian hukum karena bertujuan ketertiban masyarakat dalam menjalankan lembaga keolahragaannya. Masukan dari beberapa fraksi menginginkan KOI yang selama ini dirangkap oleh KONI, dalam RUU ini secara organisasi keduanya dipisahkan sehingga 
mulai saat ini kita mempunyai lembaga baru yaitu KOI yang khusus menangani penyelenggaraan multi kejuaraan di tingkat Internasional.

Sesuai dengan sejarah lahirnya KONI dapat diartikan bahwa induk organisasi cabang olahraga itu yaitu PSSI dan PASI membentuk KONI atau Komite Olahraga Nasional. Pasal 36 ayat (3) RUU SKN juga menjelaskan induk organisasi cabang olahraga dan Komite Olahraga Nasional sebagaimana dimaksud pada ayat (1) bersifat mandiri . Sesuai dengan posisi KONI yaitu bersifat mandiri dan hanya mendapatkan KEPPRES. Frasa Mandiri juga ditentukan oleh sebuah Undang-Undang ini juga akan membawa konsekuensi yang panjang bagi pemerintah. Tetapi dalam pembinaan dan pengembangan olahraga, KONI mendapat anggaran APBN dan di priksa Badan Pemeriksa Keuangan setiap tahunnya, walaupun dalam kedudukannya KONI masih belum jelas apakah KONI berada di bawah pemerintah atau menurut sejarahnya bersifat mandiri.

Frasa Komite Olahraga Nasional juga mengidikasikan bahwa KONI juga mempunyai tugas yang diatur dalam RUU SKN pasal 36 ayat (4) masih sama dengan UU SKN yang telah ditetapkan tanpa adanya perubahan. Akan tetapi masukan dari beberapa fraksi menginginkan KONI mempunyai tugas terbatas yaitu hanya di tingkat nasional saja. Sedangkan untuk tingkat daerah KONI membentuk KONIDA. Dapat di analisis bahwa kedudukan KONI sebenarnya tetap kabur dalam hal ini karena Frasa Komite Olahraga Nasional tidak menyebutkan secara pasti bahwa itu tugas dari KONI. Padahal tugas KONI tidak hanya membina cabang-cabang yang ada di dalam IOC atau olimpiade. KONI juga membina cabang-cabang di luar IOC oleh karena itu dalam hal ini suatu kepastian hukum harus tampak karena dalam menciptakan suatu RUU. Undang-Undang adalah keras akan tetapi memang demikan bunyinya

Analisis tentang Putusan Mahkamah Konstitusi Nomor 19/PUU-XII/2014. Penulis memasukan teori kewenangan rasional dan legal yaitu wewenang yang disandarkan pada sistem hukum yang berlaku dalam masyarakat, sistem hukum mana dipahami sebagai kaidah-kaidah yang telah diakui serta ditaati oleh masyarakat, dan bahkan yang telah diperkuat oleh negara. Wewenang tidak resmi merupakan hubungan-hubungan yang timbul antarpribadi yang sifatnya situasional, dan sifatnya sangat ditentukan pihak-pihak yang saling berhubungan tadi. Wewenang resmi sifatnya sistematis, dapat diperhitungkan dan rasional. Biasanya wewenang ini dapat dijumpai pada kelompok-kelompok besar yang memerlukan aturan tata tertib yang tegas dan bersifat tetap.

KONI sendiri memerlukan posisi yang benar meraka berada di mana dan bertindak seperti apa, karena KONI lahir dari golongan masyarakat yang membentuk KONI, Soerjono Soekanto mengemukakan pengertian wewenang adalah kekuasaan yang ada seseorang atau kelompok orang yang mempunyai dukungan atau mendapat pengakuan dari masyarakatsendiri dan sedangkan KOI adalah kepanjangan tangan dari tujuan bangsa Indonesia untuk mengikuti kejuaraan dunia maka Indonesia harus mempunyai lembaga yang bergabung di dalam IOC. Wakil Indonesia pada waktu itu adalah KONI yang 
berubah nama menjadi KOI.

Idealnya Mahkamah Konstitusi mampu melahirkan putusan yang memenuhi asas keadilan, kepastian hukum, dan kemanfaatan. Ada beberapa aspek yaitu pertama, putusan hakim merupakan penjelmaan dari hukum yang berlaku dan berguna untuk setiap orang maupun kelompok serta negara. Kedua, merupakan gambaran keseimbangan antara ketentuan hukum dan kenyataan di lapangan. Ketiga, putusan hakim harus bermanfaat bagi setiap orang dan masyarakat. Keempat, putusan hakim tidak menimbulkan konflik baru bagi para pihak dan masyarakat. Pada umumnya kepastian hukum tidak hanya meliputi ketentuan pasal-pasal aturan hukum.

\section{Akibat Hukum dari Kekaburan Norma Frasa Komite Olahraga Nasional pada pasal 36 ayat (1) dan (3) Undang-Undang Nomor 3 Tahun 2005 terhadap Pembinaan, Kedudukan KONI dan KOI.}

Pembinaan dan pengembangan olahraga prestasi dilaksanakan dan diarahkan untuk mencapai prestasi olahraga pada tingkat daerah,nasional dan Internasional. Pembinaan dan pengembangan Olahraga prestasi sebagaimana dimaksud ayat (1) di atas di lakukan oleh induk organisasi olahraga, cabang olahraga, baik di tingkat pusat maupun pada tingkat daerah.

Dalam pasal 36 penyebutan frasa "Komite Olahraga" tersebut sebenarnya bisa dikatakan itu KONI sesuai dengan Risalah Undang-Undang Rancangan Undang-Undang Sistem Keolahragaan Nasional penyebutannya dengan huruf kecil, tujuanya adalah KONI jika di tulis dengan hurus kecil yaitu Komite Olahraga Nasional menurut ahli bahasa yaitu penyebutan KONI dengan Frasa Komite Olahraga Nasional bertujuan memfokuskan kepada fungsi dari KONI tersebut yaitu sebagai pembinaan keolahragaan di tingkat nasional sesuai dengan isi dari pasal 36 ayat 4 Undang-Undang Nomor 5 Tahun 2005 tentang Sistem Keolahragaan Nasional.

Lembaga atau organ negara secara lebih dalam, kita dapat mendekatinya dari pandangan Hans Kelsen mengenai the concept of the State Organ dalam bukunya General Theory of Law and State. Hans Kelsen menguraikan bahwa "Whoever fulfills a function determined by the legal order is an organ". Siapa saja yang menjalankan suatu fungsi yang ditentukan oleh suatu tata hukum (legal order) adalah suatu organ. Artinya, organ negara itu tidak selalu berbentuk organic.

Komite Olahraga Nasional sendiri ditulis dalam huruf kecil selain untuk lebih memfokuskan kepada fungsi dari KONI juga bertujuan untuk membatasi ruang lingkupnya. Akan tetapi, dalam pemaknaan nama secara institusi tetap KONI. Bentuk Implikasi hukum dari Konflik KONI dan KOI terjadi tidak hanya tentang tumpang tindih suatu kewenangan, di luar konflik tersebut juga ada konflik tentang penggunaan lambang lima ring gelang Olimpiade oleh Komite Olahraga Nasional Indonesia (KONI) pada logonya akhirnya disepakati untuk ditanggalkan. 
Logo lima gelang tersebut pada awalnya merupakan milik Komite Olimpiade Internasional (IOC). Berdasarkan Piagam Olimpiade yang terdapat pada Olympic Charter pada bab Pelindungan Hukum Bye Law to Rules 7-14 poin 1 dan 2 yang berbunyi IOC dapat mengambil semua langkah yang tepat untuk mendapatkan perlindungan hukum untuk dirinya sendiri, baik secara nasional maupun internasional, atas hak-hak atas pertandingan Olimpiade, dan atas setiap properti olimpiade. Untuk poin keduanya berbunyi: NOC bertanggung jawab kepada IOC untuk ketaatan di negaranya, dari aturan 7-14 dan BLR 7-14 ini akan mengambil langkah-langkah untuk melarang penggunaan properti Olimpiade apapun akan bertentangan dengan peraturan tersebut demi kepentingan IOC, perlindungan atas properti olimpiade dari IOC. Lima gelang tersebut hanya boleh digunakan IOC dan anggotanya. Di Indonesia, KONI bukanlah anggota IOC. Anggotanya adalah Komite Olimpiade Indonesia (KOI). Konflik semakin meluas ke masalah yang lain tentang pembinaan dan pengembangan olahraga di Indonesia.

KONI dalam tugasnya melaksanakan pengelolaan, pembinaan dan pengembangan olahraga pada tingkat nasional. Akan tetapi dalam menjalankannya KONI berselisih dengan KOI tentang masalah kewenangan dan adanya tumpang tinding dalam pembinaan keolahragaan yang juga di mana KONI dan KOI mempunyai salah satu tugas meningkatkan dan memelihara kepentingan Indonesia serta memperoleh dukungan masyarakat" untuk mengikuti Olympic Games, Asian Games, East Asia Games serta Pekan Oalahraga International. Pengartian dukungan masyarakat pada pasal 44 ayat (3) Undang-Undang No 3 Tahun 2005 tentang Sistem Keolahragaan Nasional adalah Induk Organisasi cabang Olahraga yang berafiliasi dengan Federasi Cabang Olahraga International. Yang dimaksud adalah KONI melakukan pembinaan dan pengembangan kemudian KOI memberangkatkan hasil dari pembinaan KONI untuk berlomba di ajang Internasional. Karena tidak adanya kepastian hukum secara hiraki di mana harus adil dan pasti. Pasti sebagai pedoman kelakukan dan adil karena pedoman kelakuan itu harus menunjang suatu tatanan yang dinilai wajar. Hanya karena bersifat adil dan dilaksanakan dengan pasti hukum dapat menjalankan fungsinya. Kepastian hukum merupakan pertanyaan yang hanya bisa dijawab secara normatif, bukan sosiologi .karena tidak ada suatu kepastian hukum tersebut terjadinya tumpang tindih dalam kewenangan.

Penulis akan menjelaskan dari sisi KOI. Dari penjelasan diatas KOI dalam meningkatkan prestasi olahraga dan juga mempunyai kewajiban yang didukung oleh Pasal 8 Huruf "c" Peraturan Pemerintah Nomor 17 Tahun 2007 dalam penyelenggaraan Pekan dan Kejuaraan Olahraga yang berbunyi: melibatkan induk cabang Organisasi olahraga yang dipertandingkan dalam perencanaan, persiapan dan pelaksanaan keikutsertaan Indonesia dalam Pekan Olahraga Internasiona .

Berdasarakan pasal 8 huruf "c" Peraturan Pemerintah Nomor 17 Tahun 2007 dalam penyelenggaraan Pekan dan Kejuaraan Olahraga. KOI dapat melibatkan induk organisasi cabang olahraga dalam masalah perencanaan, persiapan dan pelaksanaan keikutsertaan 
Indonesia dalam Pekan Olahraga Internasional. Tugas dan kewenenangan tersebut terjadi tumpang tindih dengan KONI, karena tugas dan fungsi ini baik dalam melakukan perencanaan, persiapan dan pelaksanaan pembinaan olahraga prestasi menjadi tanggung jawab induk organisasi cabang olahraga di bawah Kordinasi KONI sesauai dengan Pasal 36 Ayat (4) pada huruf "b" dan "c" Undang-Undang Nomor 3 Tahun 2005 tentang Sistem Keolahragaan Nasional. Pasal ini yang menyebabkan konflik tumpang tindih kewenangan antara KONI dan KOI. Hal ini dikarenakan KOI dalam menjalankan tugasnya sesuai dengan pasal 8 Huruf “c” PP No 17 Tahun 2007 ikut melibatkan induk cabang olahraga dalam perencanaan, persiapan dan pelaksanaan keikutsertaan tim dan kontingen Indonesia dalam kejuaraan International. Amanah tersebut seharusnya merupakan tugas dari KONI dengan dasar hukum UU No 3 Tahun 2005 tentang Sistem Keolahragaan yang jelas lebih tinggi daripada PP tersebut.

Hal ini sesuai dengan pendapat Stoner, bahwa konflik organisasi adalah ketidaksesuaian antara dua orang anggota organisasi atau lebih yang timbul karena fakta bahwa mereka harus berbagi dalam hal mendapatkan sumber daya terbatas, atau aktivitas pekerjaan, dan atau karena fakta mereka memiliki status, tujuan nilai-nilai presepsi yang berbeda karena seharunya tugas KOI hanya sebagai penyelengara dan pemberakatan atlet ke ajang International, sesuai dengan Pasal 44 ayat (3) UU No 3 Tahun 2005 yang berbunyi Komite Olimpiade Indonesia meningkatkan dan memelihara kepentingan Indonesia, serta memperoleh dukungan masyarakat untuk mengikuti Olympic Games, Asian Games, South East Asia Games, dan Pekan Olahraga Internasional lain. ${ }^{10}$

\section{Rekonstruksi terhadap Undang-Undang Nomor 3 Tahun 2005 Tentang Sistem Keolahragaan Nasional untuk Mempersatukan KONI dan KOI.}

Penulis akan membandingkan sistem hukum keolahragaan dari negara-negara lain seperti Jerman, Jepang, USA. Penulis memilih negara Jerman karena Jerman memiliki sistem pemerintahan yang sama dengan Indonesia yaitu civil law. Sehingga lebih mempermudah dalam penyesuaian ke dalam sistem pemerintah yang ada di Indonesia. Yang kedua, penulis membandingkan dengan negara Jepang karena negara besar di Asia yang mempunyai budaya taat kepada aturan dan teknologi menjadi salah satu keunggulan dalam pembinaan keolahragaan. Jepang negara yang dalam keolahragaannya juga menjadi salah satu macan Asia. Yang ketiga dengan negara USA, penulis memilih negara ini di karenakan USA adalah negara besar yang tersebar dengan negara-negara bagian. Dari sisi tersebut penulis membandingkan sistem keolahragaannya dengan negara bagian yang besar dan bagaimana proses pembinaannya sehingga dapat kita lihat negara tersebut sangat sukses dalam pembinaan keolahragaannya.

Negara Jerman sendiri juga mengalami peleburan dua lembaga olahraga yaitu DOSB dan KONI pada tahun 2006 untuk urusan dalam negeri dimasukan kedalam DOSB sendiri

\footnotetext{
${ }^{10}$ Seperti dikutip dari laman www.kemenpora.go.id
} 
mulai dari pengembangan olahraga yang baru sekaligus dalam olahraga yang sesuai dengan olimpiade dan juga mempunyai program-program sendiri. Karena satu pintu melalui DOSB, minim terjadi konflik tumpang tindih kewenangan karena semua mempunyai bagian masing-masing. Dari negara Jepang juga hanya ada satu lembaga keolahragaan yaitu JOC yang di dalamnya juga mengatur seluruh Induk olahraga dalam negeri, contohnya seperti JFA (PSSInya Jepang) dll, dalam pembinaan Jepang juga melibatkan Ilmu Pengetahuan dan Teknologi dalam pengembangan keolahragaannya.

Terakhir adalah USA negara yang sangat besar ini pasti mempunyai sistem keolahragaan yang terorganisir sehingga mampu membina dan berprestasi di internasional. USA mempunyai program untuk para atlet dan Badan Pimpinan Nasional mereka. Selain hibah kinerja dan penghargaan, dukungan tambahan diberikan dalam bentuk fasilitas pelatihan, kedokteran dan ilmu olahraga, pendidikan pelatihan, asuransi kesehatan, peluang promosi, layanan pendidikan dan karier, perlengkapan dan perjalanan serta olahraga yang aman dan pemrograman anti-dopin, teknologi dalam pengembangan olahraga tak kalah penting USA ketika M.F siregar mengujungi pusat latihan USA untuk persiapan Olimpiade Beijing 2008.

Peleburan KONI dan KOI sebenarnya pernah dilakukan Indonesia pada tahun 1951, tujuan singkat peleburan tersebut sebagai keinginan Indonesia untuk mengikuti olimpiade di Helsinki dan Asian Games di New Delhi. Di karenakan Indonesia diharuskan mempunyai lembaga yang terdaftar di dalam IOC International Olimpiade Comunite agar dapat mengikuti kejuaraan tersebut sesuai dengan isi Piagam Olimpiade . Sesuai dengan perbandingan sistem keolahragaan pada negara-negara tersebut, mereka hanya mempunyai satu induk lembaga keolahragaan dan di dalamnya terdapat beberapa cabang induk olahraga atau Federasi Olahraga Nasionalnya.

Peleburan KONI dan KOI pada saat ini dibutuhkan agar tidak terjadinya tumpang tindih dalam kewenangan masalah pembinaan keolahragaan. Peleburan ini didasarkan atas pentingnya suatu kelembagaan yang bagus. Pada dasarnya organisasi dibentuk untuk mempermudah tugas dari manusia karena sebagai individu manusia tidak dapat serta merta menyelesaikan segala sesuatu dengan usaha sendiri. Oleh karena itu diperlukannya peleburan KONI dan KOI agar dapat menaungi semua keolahragaan di Indonesia agar terciptanya iklim yang baik bagi Sistem Keolahragaan di Indonesia dengan masalah pembinaan di mana lebih mempunyai program kerja standar pencetakan atlet yang baik dan mempunyai kurikulum yang bagus sehingga peleburan ini memang di perlukan. serta masalah penyelengaraan olahraga yang sesuai dengan standart internasional dalam hal ini lebih menekankan bawah perlombaan tingkat daerah diambil alih oleh induk dari cabangcabang olahraga selanjutnya untuk tingkat nasional lembaga tersebut juga bisa fokus kejuaraan yang berpotensi menghasilkan medali yang banyak bagi Indonesia akan tetapi tidak menyampingkan olahraga yang lain.

Peleburan KONI dan KOI juga menyatukan tujuan organisasi kelembagaan. 
Albertus, mengatakan tujuan organisasi lebih penting daripada tujuan kelompok/unit. Pengertian dari pernyataan tersebut adalah bahwa tujuan berorganisasi dijadikan pangkal utama sehingga dapat mengajak setiap kelompok atau organisasi untuk saling bahu membahu untuk mencapai tujuan negara dan meminimalisir terjadinya konflik internal dipisahkan KONI-KOI juga membuka peluang sejumlah induk-induk olahraga membentuk organisasi baru sehingga melahirkan dualisme kepengurusan. Memperbaiki masalah komunikasi antara KONI dan KOI yang buruk juga menjadi salah satu faktor permasalahan tersebut yang berakibat turunya prestasi Indonesia. Penulis mempunyai konsep tugas dan fungsinya. Berdasarkan analisis dan pertimbangan di atas, efisiensi dan efektivitas dan adanya tumpang tindah Tupoksi menyatukan kembali tugas dan fungsi kelembagaan organisasi KONI serta tugas dan fungsi kelembagaan olahraga KOI ke dalam satu wadah yaitu "Komite Olahraga Nasional Indonesia" (KONI). ${ }^{11}$

Peleburan KONI dan KOI otomatis juga berhubungan dengan siapa yang memimpin organisasi keolahragaan tersebut. Untuk menjawab rumusan masalah ketiga ini penulis mempunyai konsep yaitu mengapa dibutuhkan pemimpin satu dalam memimpin suatu organisasi/lembaga yang mempunyai tujuan sama yaitu membina dan meningkatkan prestasi Indonesia agar lebih baik lagi. Terakhir penulis mempunyai Konsep Rekonstruksi dalam UU SKN memperjelas frasa yang memiliki kekaburan sehingga menimbulkan konflik, memperjelas ketua lembaga yang diatur dalam UU SKN serta memperbaiki beberapa pasal yang harus disesuaikan dengan situasi saat ini.

\section{E. PENUTUP}

Berdasarkan analisis dan pembahasan diatas, kedudukan KONI dan KOI dalam pembinaan keolahragaan Undang-Undang No 3 Tahun 2005 tentang Sistem Keolahragaan Nasional pada pasal 36 ayat (1) dan (3) mengalami kekaburan Norma pada Frasa Komite Olahraga Nasional dimana KONI dan KOI dalam menjalankan tugasnya sering terjadi tumpang tindih tugas dan wewenang sehingga mengakibatkan kerugian yang besar bagi kedua lembaga keolahragaan dan bagi prestasi keolahragaan di Indonesia yang terus menurun prestasinya.

1. Penyebab kekaburan norma Frasa Komite Olahraga Nasional tersebut bermula ketika Undang-Undang No 3 Tahun 2005 tentang Sistem Keolahragaan Nasional di sahkan dan di terbitkan. KONI mempunyai tugas tentang pembinaan dan pengembangan atlet di dalam negeri dan KOI memberangkat atlet ke perlombaan di luar negeri dan menyelenggrakan event olahraga internasional. Risalah Rancangan UU SKN KONI diartikan dalam huruf kecil dengan frasa Komite Olahraga Nasional dengan tujuan untuk membatasi kewenangan KONI agar tidak terlalu luas, tetapi dalam pelaksanaannya, frasa Komite Olahraga Nasional tetap dijalankan oleh KONI sesuai

11 Komite Olahraga Nasional Indonesia, Sejarah KONI, https://koni.or.id/index.php/id/aboutus/sejarah?showall=1\&start=0 diakses 23 Februari 2019 
dengan isi Pasal 36 Ayat (4) Undang-Undang Nomor 3 Tahun 2005 tentang Sistem Keolahragaan Nasional. Selanjutnya, KOI secara tegas juga di tulis dalam Pasal 44 ayat (1),(2),(3) dan (4) Undang-Undang No 3 Tahun 2005 tentang Sistem Keolahragaan Nasional hanya melakukan pemberangkatan atlet ke ajang internasional dan mengadakan perlombaan internasional.

2. Bentuk implikasi hukum dari kekaburan norma yang ada didalam pasal 36 ayat (1) dan (3) Undang-Undang Nomor 3 Tahun 2005 tentang sistem Keolahragaan Nasional. Terjadinya tumpang tindih kewenangan, KONI mempunyai tugas tentang pembinaan dan pengembangan atlet di dalam negeri dan KOI memberangkat atlet ke perlombaan di luar negeri dan menyelenggarakan event olahraga internasional. akan tetapi karena frasa Komite Olahraga Nasional tidak di pahami sebagai KONI dalam UndangUndang No 3 Tahun 2005 tentang Sistem Keolahragaan Nasional tersebut, KOI ikut melaksanakan tugas tersebut dengan didukung pasal 8 huruf 'a','b','c', dan 'd', pada Peraturan Pemerintah No 17 Tahun 2007 tentang Penyelenggaraan Pekan dan Kejuaraan Olahraga.

3. Konsep Rekonstruksi dalam Undang-Undang No 3 Tahun 2005 tentang Sistem Keolahragaan Nasional. Penulis membandingkan sistem hukum keolahragaan dari 4 negara yang cukup baik dalam mengelola sistem hukum keolahragaan. Konsep mempersatukan KONI dan KOI menjadi sutu wadah kelembagaan keolahragaan agar mengurangi konflik. Jika KONI dan KOI dilebur menjadi satu lembaga keolahragaan maka akan berimbas siapa yang memimpin, dalam hal ini penulis memberikan konsep jika KONI dan KOI selanjutnya akan di pimpin oleh satu ketua saja agar tidak lagi menjadi masalah tumpang tindih dalam pengaturannya. Konsep Rekonstruksi dalam UU SKN memperjelas frasa yang memiliki kekaburan sehingga menimbulkan konflik, memperjelas ketua lembaga yang diatur dalam UU SKN serta memperbaiki beberapa pasal yang harus disesuaikan dengan situasi saat ini. Hal ini dapat dipahami bahwa pembaharuan bukanlah menampilkan sesuatu yang benar-benar baru, namun lebih tepatnya merekonstruksi kembali kemudian menerapkannya dengan realita saat ini.

\section{DAFTAR PUSTAKA}

Admin, Japan

Restoration

Project, https://www.bulutangkis.com/mod.php?mod=publisher\&op=printarticle\&artid=3079 diakses 22 Februari 2019

Departemen Pendidikan Nasional, Sejarah Lembaga Keolahragaan di Indonesia, Jakarta: 2003.

Der Deutsch Olympische Sportbund, Das ist Der Dosb https://www.dosb.de/ueber-uns/ diakses 21 Februari 2019

H.J.S. Husdarta. Sejarah dan Filsafat Olahraga, Bandung: 2010. 
Japanesse Olympic Comitee, About JOC, https://www.joc.or.jp/english/aboutjoc/ diakses 21 Februari 2019

Jimly School, Sejarah Constitutional Review Gagasan Pembentukan MK, http://jimlyschool.com/read/analisis/276/sejarah-constitutional-review-gagasanpembentukan-mk/ diakses 21 Februari 2019

Kementrian Pendayagunaan Aparatur Negara dan Reformasi Birokrasi, Lembaga Non Struktural, $\quad$ http://www.menpan.go.id/kelembagaan/549-lembaga-non-struktural diakses 14 November 2018

Keputusan Presiden No. 94 Tahun 1962 tentang Regrouping dan Susunan Baru Kabinet Kerdja.

Komite Olahraga Nasional Indonesia, Sejarah KONI, https://koni.or.id/index.php/id/aboutus/sejarah?showall=1\&start=0 diakses 23 Februari 2019

Komite Olahraga Nasional Indonesia, Tentang KONI, https://koni.or.id/index.php/id/aboutus/14-tentang-koni diakses 7 Februari 2019

Komite Olahraga Nasional Indonesia, Susunan Pengurus Koni Pusat Masa Bakti 2015-2019, http://www.koni.or.id/index.php/id/about-us/pengurus diakses 13 November 2018

Peraturan Pemerintah Republik Indonesia Nomor 16 Tahun 2007 Tentang Penyelenggaraan Keolahragaan. Peraturan Pemerintah No 17 tahun 2007 Tentang Penyelenggaraan pekan dan Kejuaraan Oalahraga

Peter Mahmud Marzuki, Penelitian Hukum, Kencana Prenada Media Group, Jakarta: 2005.

Philipus M. Hadjon, Ide Negara Hukum dalam Sistem Ketatanegaraan Republik Indonesia, Makalah pada Bagir Manan (Ed). Kedaulatan Rakyat, Hak Asasi Manusia, dan Negara Hukum, Kumpulan Esai Dalam Rangka 70 Tahun R. Sri Soemantri Martosoewignjo, Gaya Media Pratama, Jakarta: 1996.

Putusan Mahkamah Konstitusi Nomor 19/PUU-XII/2014 dalam permasalahn pengujian Undang-Undang Nomor 3 Tahun 2005 tentang Sistem Keolahragaan Nasional, amar putusan

Rusli Lutan, Indonesia and the Asian Games: Sport, Nationalism and the "New Order" artikel dalam Sport, Nationalism and the Asian Games, London and New York: Routlege, Taylor \& Francis Grup 2007.

Sjahran Basah, Eksistensi dan Tolok Ukur Badan Peradilan Administrasi di Indonesia, Alumni, Bandung, 1985.

Undang Undang Dasar Negara Republik Indonesia Tahun 1945.

Undang-Undang Nomor 3 Tahun 2005 tentang Sistem Keolahragaan Nasional.

Wienakto dan Soetopo, Kisah-kisah Asian Games, Jakarta: PT. Mustrivo, 1958. 